\title{
Hubungan Kadar Glutamic Oksaloasetat Transaminase Dengan Lama Perawatan Pasien Infark Miokard Akut di RSUP. Dr. M. Djamil Periode Januari-Desember 2013
}

Ardho Mahamada ${ }^{1}$, Yerizal Karani ${ }^{2}$, Rismawati Yaswir $^{3}$

\begin{abstract}
Abstrak
Infark Miokard Akut (IMA) merupakan salah satu penyebab kematian utama di dunia. Beberapa enzim, salah satunya adalah Serum Glutamic Oksaloasetat Transaminase (SGOT),dilepaskan pada saat proses terjadinya infark miokard. Tujuan penelitian ini adalah untuk mengetahui hubungan kadar SGOT dengan lama perawatan pasien IMA yang hasilnya dapat digunakan sebagai penentuan perawatan pasien Infark. Penelitian ini merupakan studi analitik retrospektif dengan desain cross sectional menggunakan data sekunder dari rekam medik 51 pasien IMA yang dirawat di Cardio Vascular Care Unit (CVCU) RSUP dr M. Djamil Padang periode Januari-Desember 2013. Hasil penelitian menunjukkan rerata kadar SGOT 187,529 \pm 133,6 $\mu / \mathrm{L}$. Hasil analisis dengan uji korelasi Spearman menunjukkan terdapat korelasi positif antara kadar serum SGOT dengan lama rawat pasien IMA di RSUP Dr. M. Djamil Padang. Korelasi tersebut bernilai sedang dan bermakna secara statistik $(r=0,437, p<0,05)$. Hal ini menunjukkan semakin tinggi kadar SGOT serum pasien, semakin meningkat lama rawat pasien tersebut.
\end{abstract}

Kata kunci: infark miokard akut, SGOT, lama rawat

\section{Abstract}

Myocardial Infarction (MI) is one of the major cause of death on population in the world. Certain enzymes, such as Glutamic Oxaloacetate Transaminase that increase during myocardial infarction. The objective of this study was to determine the correlation between Glutamic Oxaloacetate Transaminase Serum levels and length of hospitalization in myocarial infarction patients, in order to provide treatment recommendation on patients. The study was a retrospective analytic research with cross sectional design using secondary data of 51 myocardial infarction patients hospitalized in Cardiovascular Care Unit (CVCU) M. Djamil Hospital from January to December 2013. The results showed that Glutamic Oxaloacetat Transaminase serum level rate is 187,529 $\pm 133,6 \mu / \mathrm{L}$. The analytical results using Spearman test showed there is a possitive correlation between and length of hospitalization in myocardial infarction patients at RSUP Dr. M. Djamil Padang. The correlation is moderate and significant ( $p$-value $>0,05, r=0,437$ ). This indicates a higher level of SGOT serum patients followed by increasing patients hospitalization.

Keywords: acute myocardial infarction, glutamic oxaloacetate transaminase, length of hospitalization

Affiliasi penulis: 1. Prodi Profesi Dokter FK Unand (Fakultas Kedokteran Universitas Andalas Padang), 2. Bagian Kardiologi FK Unand/RSUP Dr. M.Djamil Padang, 3. Bagian Patologi Klinik FK Unand

Korespondensi: Ardho Mahamada, Email: ardhom122@yahoo.com Telp: 082169919223

\section{PENDAHULUAN}

Infark Miokard Akut (IMA) adalah suatu keadaan dimana suplai darah pada suatu bagian jantung terhenti sehingga sel otot jantung mengalami kematian. ${ }^{1}$ Penyakit jantung merupakan penyakit dengan peringkat ke - 4 dari 10 penyebab kematian 
terbanyak di kota Padang tahun 2011 dengan jumlah kasus mortalitas sebanyak 60 kasus. $^{2}$

Pasien dengan IMA membutuhkan perawatan selama di rumah sakit untuk meringankan nyeri dada, terapi perfusi untuk mencegah luasnya infark yang lebih lanjut, dan memulai tahap pencegahan sekunder yang diperlukan. ${ }^{3}$ Pedoman yang ditetapkan oleh Amerika Serikat dan Eropa merekomendasikan perawatan di rumah sakit tidak boleh melebihi 4 hari untuk kasus yang tidak ada komplikasi. ${ }^{4}$

Diagnosis IMA menurut World Health Organization (WHO) seperti yang dikutip oleh Irmalita (2011) ditegakkan jika paling sedikit diperoleh dua dari tiga kelainan, diantaranya : 1) manifestasi klinis : nyeri dada tipikal (angina) $\geq 20$ menit, 2) abnormailtas EKG yang spesifik (segmen ST elevasi, gelombang $Q$ patologis, ST depresi atau inversi gelombang T), dan 3) peningkatan kadar enzim kardiak serum (Troponin T, troponin I, SGOT/SGPT, CK-MB, dan lain-lain). ${ }^{5}$

Infark Miokard ditandai dengan pelepasan enzim-enzim yang terdapat pada sel otot jantung yang mengalami nekrosis maupun petanda spesifik jantung lainnya. Salah satu enzim yang dilepaskan pada saat terjadinya infark yaitu serum glutamic oksaloasetat transaminase (SGOT). ${ }^{6}$ Enzim ini mengalami peningkatan setelah delapan jam terjadinya cedera / kerusakan pada sel dan mencapai kadar puncaknya dalam waktu 24-36 jam sampai kembali ke kadar normal dalam waktu tiga sampai tujuh hari. Walaupun kurang spesifik dibandingkan pemeriksaan biomarker jantung lainnya, SGOT bisa membantu pemeriksaan dalam menilai progresivitas terjadinya infark. ${ }^{7}$

Selama ini, penelitian ini belum ada di RSUP dr. M. Djamil Padang sehingga perlu untuk dilakukan penelitian tentang hubungan kadar SGOT serum dengan lama perawatan pasien IMA di RSUP Dr. M. Djamil Padang sebagai modalitas prognostik untuk menentukan perawatan pasien IMA.

\section{METODE}

Jenis penelitian ini adalah analitik retrospektif. Populasi adalah semua data sekunder pasien infark miokard yang dirawat di Cardio Vascular Care Unit
(CVCU) RSUP Dr. M. Djamil Padang. Seluruh populasi dijadikan sampel dengan kriteria inklusi seluruh pasien IMA dengan ST-elevasi dengan data yang lengkap dari periode Januari-Desember 2013. Variabel penelitian ini adalah umur, jenis kelamin, kadar SGOT, dan lama rawat pasien.

Data penelitian yang diperoleh dijelaskan secara analitik baik univariat maupun bivariat. Analisis univariat digunakan untuk melihat distribusi frekuensi karakteristik pasien, variabel independen, dan variabel dependen. Analisis bivariat digunakan untuk mengetahui ada atau tidaknya hubungan antara variabel independen (kadar SGOT) terhadap variabel dependen (lama perawatan pasien infark miokard) dengan menggunakan uji korelasi Spearman.

Hasil

Karakteristik pasien Infark Miokard dengan STElevasi berdasarkan usia dan jenis kelamin

Didapatkan 51 pasien yang memenuhi kriteria inklusi yang dirawat di CVCU RSUP Dr. M. Djamil Periode Januari-Desember 2013. Pada penelitian ini didapatkan pasien STEMI terbanyak pada kelompok usia 60-69 tahun yaitu 24 pasien $(47,1 \%)$. Usia termuda pada sampel penelitian ini adalah 28 tahun dan usia tertua adalah 75 tahun.

Dari total 51 pasien, diketahui pasien laki-laki lebih banyak dibandingkan perempuan. Laki-laki sebanyak 43 pasien $(84,3 \%)$ dan perempuan $(15,7 \%)$.

Tabel 1. Karakteristik sampel berdasarkan usia dan jenis kelamin

\begin{tabular}{llll}
\hline No & Karakteristik & $\mathbf{n = 5 1}$ & $\%$ \\
\hline $\mathbf{1}$ & Usia & & \\
& $<40$ & 1 & 2,0 \\
& $40-49$ & 2 & 3,9 \\
& $50-59$ & 13 & 25,5 \\
& $60-69$ & 24 & 47,1 \\
& $>70$ & 11 & 21,6 \\
& & & \\
& Jenis Kelamin & & \\
& Laki-laki & 43 & 84,3 \\
& Perempuan & 8 & 15,7 \\
& & &
\end{tabular}




\section{Kadar SGOT Serum}

Berdasarkan kadar SGOT serum yang diperiksa pada data pasien, didapatkan sebagian besar sampel mengalami peningkatan kadar SGOT dengan kadar $>35 \mu / l(88,2 \%)$. Nilai kadar SGOT terendah dari penelitian ini adalah $20 \mu / l$ dan nilai kadar SGOT tertinggi adalah $523 \mu / /$.

Tabel 2. Karakteristik sampel berdasarkan kadar SGOT pasien

\begin{tabular}{ccc}
\hline Kadar SGOT $(\boldsymbol{\mu} / \mathbf{l})$ & $\mathbf{n}$ & $\%$ \\
\hline $0-35$ & 6 & 11,8 \\
$>35$ & 45 & 88,2 \\
\hline Jumlah & 51 & 100 \\
\hline
\end{tabular}

\section{Lama Perawatan Pasien}

Berdasarkan lama perawatan yang diperiksa pada data pemeriksaan pasien, didapatkan sampel terbanyak adalah pasien dengan lama rawat dibawah 5 hari $(92 \%)$.

Tabel 3. Karakteristik lama perawatan pasien

\begin{tabular}{ccc}
\hline Lama Perawatan & $\mathbf{n}$ & $\%$ \\
\hline$\leq 5$ hari & 47 & 92,2 \\
$>5$ hari & 4 & 7,8 \\
\hline Jumlah & 51 & 100 \\
\hline
\end{tabular}

\section{Hubungan antara kadar SGOT dengan lama perawatan pasien Infark Miokard}

Uji normalitas data pada penelitian ini menggunakan metode analitik Kolmogorov-Smirnov(a) karena jumlah sampel lebih dari 50. Distribusi variabel kadar SGOT sampel adalah normal karena $p>0,05$, sedangkan distribusi variabel lama perawatan pasien tidak normal karena $p<0,05$. uji statistik yang digunakan adalah uji Spearman karena distribusi data yang didapat tidak normal.

Analisis bivariat dilakukan dengan uji korelasi Spearman karena salah satu variabel (lama rawat) berdistribusi tidak normal. Hasil uji analisis Spearman memperlihatkan hubungan antara kadar SGOT dengan lama perawatan pasien Infark Miokard periode Januari-Desember 2013. Terdapat korelasi positif antara keduanya. Nilai korelasi tersebut kuat sedang $(r=0,437)$ dan bermakna secara statistik. Nilai $p$ menunjukkan $<0,05$, hal ini berarti hipotesis diterima.

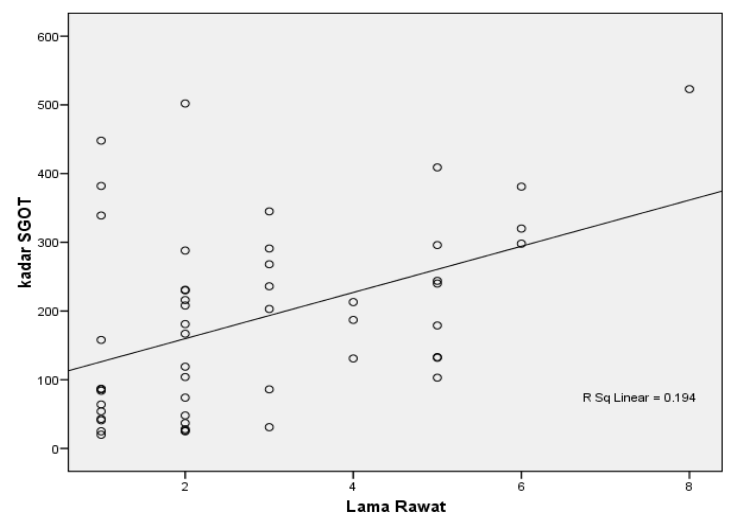

Gambar 1. Hubungan kadar SGOT dengan lama perawatan pasien infark miokard

\section{PEMBAHASAN}

Karakteristik pasien Infark Miokard dengan STElevasi berdasarkan usia dan jenis kelamin

Penelitian yang dilakukan di bagian RSUP Dr. M. Djamil Padang dengan jumlah sampel 51 rekam medis pasien IMA dengan STEMI yang dirawat di bagian CVCU RSUP Dr. M. Djamil Padang pada periode Januari - Desember 2013 memperoleh rentang usia 28-75 tahun dengan rerata usia 54,14 tahun. Kelompok usia terbanyak adalah 60-69 sebanyak $47,1 \%$ (24 pasien). Hasil ini sejalan dengan penelitian Wagyu pada tahun 2010 yang melaporkan sebanyak 33,73\% pasien STEMI yang dirawat di BLU RSUP Prof. Dr. D. Kandou Manado berusia 60-69 tahun dengan jumlah pasien sebanyak 28 pasien. ${ }^{8}$ Lain halnya pada penelitian yang dilakukan Lazzeri et al pada tahun 2010 , didapatkan rata-rata usia pasien STEMI adalah 67 tahun. ${ }^{9}$

Etiologi utama terjadinya IMA adalah aterosklerosis. Terdapat beberapa faktor risiko yang saling berkaitan dalam mempercepat proses aterosklerosis, salah satunya adalah usia. Kerentanan terhadap aterosklerosis meningkat seiring bertambahnya usia. Insiden MI meningkat hingga lima kali lipat pada usia 40-60 tahun. ${ }^{10}$

Berdasarkan distribusi jenis kelamin, didapatkan perempuan sebesar 8 pasien $(15,7 \%)$ dan 
laki-laki 43 pasien $(84,3 \%)$. Hal ini serupa dengan hasil penelitian Wagyu pada tahun 2010 yang melaporkan sebanyak $84,34 \%$ pasien STEMI berjenis kelamin laki-laki dan $15,66 \%$ berjenis kelamin perempuan. ${ }^{8}$ Hasil penelitian Viola et al pada tahun 1999 didapatkan sebanyak 155.565 (40,4\%) pasien berjenis kelamin perempuan dan 229.313 (59,5\%) berjenis kelamin laki-laki. ${ }^{11}$ Penelitian Steyn et al pada tahun 2005 didapatkan sebanyak 75,9\% dari 12.461 kasus STEMI berjenis kelamin laki-laki. ${ }^{12}$

Berdasarkan hasil penelitian tersebut, risiko aterosklerosis koroner lebih besar pada laki-laki dibandingkan perempuan. Salah satu teori yang berkaitan adalah efek perlindungan estrogen dianggap menjelaskan adanya imunitas wanita pada usia sebelum menopause. Namun, sejauh ini belum ada alasan yang kuat tentang teori tersebut. ${ }^{10}$ Dalam hal perbandingan usia, prevalensi $\mathrm{Ml}$ akan meningkat bersama usia dengan puncak pada 55-64 tahun pada kelompok pria dan diatas usia 70 tahun pada wanita. ${ }^{13}$

Kadar SGOT yang diperoleh menunjukkan sebanyak 45 pasien $(88,2 \%)$ mempunyai kadar SGOT diatas normal $(>35 \mu / \mathrm{l})$, sedangkan 6 pasien $(11,8 \%)$ menunjukkan tidak mengalami peningkatan kadar SGOT. Nilai rata-rata SGOT yang didapatkan dari seluruh pasien sebesar $187,529 \pm 133,6 \mu / \mathrm{L}$. Hasil ini sejalan dengan penelitian yang dilakukan Kurniawan pada tahun 2010 yang melaporkan rerata kadar SGOT dari 72 pasien sebesar 132,9 $\pm 245,2 \mu / .^{6}$ Berdasarkan penelitian yang dilakukan Peppes et al pada tahun 2008 di Rumah Sakit Alexandra, Yunani, rerata kadar SGOT yang diambil pada 65 pasien IMA sebesar 154,2 $\pm 141,7 \mu /$ L. $^{14}$

Meningkatnya kadar SGOT pada pasien IMA diakibatkan adanya kerusakan sel miokardium sehingga menyebabkan kematian jaringan pada miokardium. SGOT akan memuncak kadarnya dalam 36 jam pasca onset gejala dan kembali ke normal setelah 4 hari. $^{15}$

Hasil penelitian ini mendapatkan jumlah subjek penelitian dengan lama perawatan kurang dari sama dengan 5 hari sebanyak 47 pasien $(92,2 \%)$, sedangkan jumlah subjek penelitian dengan lama perawatan lebih dari 5 hari sebanyak 4 pasien $(7,8 \%)$. $\mathrm{Hal}$ ini sesuai dengan Clinical Pathway Ruang CVCU
RSUP M. Djamil Padang yang menetapkan perawatan pasien IMA selama 5 hari.

Hal ini sejalan dengan penelitian Saputra pada tahun 2013 yang melaporkan sebanyak 105 pasien (76,6\%) mendapatkan lama rawat kurang dari sama dengan 7 hari dan 32 pasien (23,4\%) mendapatkan perawatan lebih dari 7 hari. ${ }^{16}$ Berdasarkan penelitian Pratiwi pada tahun 2011 melaporkan rata-rata lama rawat pasien STEMI yang dirawat di RSUP Dr. Kariadi Semarang sebesar 6,6 \pm 3,5 hari pada pasien yang mendapat reperfusi dan $8,7 \pm 5,1$ hari pada pasien yang tidak mendapat reperfusi jaringan.Berdasarkan hasil penelitian tersebut didapatkan bahwa terapi reperfusi dan $\mathrm{PCl}$ mempengaruhi lama perawatan pasien. $^{17}$

Secara umum hasil uji korelasi kadar SGOT dengan lama rawat pasien IMA menunjukkan terdapat hubungan antara kedua variabel karena $p<0,05$. Kedua variabel berkorelasi sedang $(r=0,437)$ dan arahnya positif.

Menurut penelitian Kurniawan dan Bahrun pada tahun 2012 pada uji korelasi antara kadar transaminase dengan mortalitas dan lama perawatan pasien IMA menunjukkan kadar SGOT terdapat hubungan positif bermakna terhadap lama perawatan $(p=0,006, r=0,389)^{6}$

Peningkatan kadar SGOT serum pada infark miokard behubungan dengan luasnya infark miokard pasien. Pada peneltian ini ditemukan kadar SGOT lebih bermakna dibandingkan kadar SGPT karena aktivitas SGOT pada jantung lebih spesifik dibandingkan SGPT sehingga peningkatan SGPT selain disebabkan infark miokard dapat juga diakibatkan oleh penyakit selain jantung. ${ }^{6}$ Proses terjadinya nekrosis pada miokardium ditandai dengan peningkatan serum enzim seperti CPK, AST, LDH, dan troponin akibat kerusakan sel miokard. Peningkatan enzim miokardium berhubungan dengan meningkatnya keparahan dari Coronary Artery Disease (CAD) yang secara langsung berkaitan dengan proses terjadinya infark miokard secara meluas. ${ }^{14}$

Proses perluasan terjadinya infark miokard akan diikuti dengan lama rawat yang juga semakin meningkat dikarenakan dibutuhkan pemantauan lebih 
lanjut terhadap pasien. Lama perawatan juga dipengaruhi oleh reperfusi yang diberikan, karena mencegah perluasan infark miokard ke tahap lebih lanjut. ${ }^{17}$

Terapi reperfusi bertujuan untuk membatasi luasnya daerah infark miokard, yang sangat menentukan prognosis dari pasien. Bila STEMI terjadi dalam waktu 12 jam setelah onset gejala, terapi reperfusi perlu dilakukan secepatnya. Jika lebih dari 12 jam dari onset gejala, terapi reperfusi diberikan kalau masih ada tanda-tanda iskemia. Teknik reperfusi mencakup dua cara, intervensi koroner perkutan primer (primary Percutaneous Coronary Intervention) dan penggunaan obat fibrinolitik. Obat fibrinolitik yang diberikan adalah streptokinase dosis 1,5 juta unit diberikan selama 30-60 menit. $^{5}$

Selain dilakukan intervensi perfusi koroner, suplemen oksigen diberikan pada pasien STEMI. Pemberian oksigen dapat dilakukan dengan sungkup oksigen selama 6 jam pertama dengan dosis 4-12 L/menit. ${ }^{18}$

\section{SIMPULAN}

Terdapat korelasi antara kadar SGOT dengan lama perawatan pasien IMA yang di rawat di CVCU RSUP M. Djamil Padang Periode Januari-Desember 2013. Nilai koefisien korelasi antara kadar SGOT dengan lama perawatan pada penelitian ini adalah 0,437, kekuatan korelasi sedang dan arah korelasi positif. Semakin tinggi kadar SGOT serum pasien diikuti dengan meningkatnya lama rawat pasien.

\section{UCAPAN TERIMA KASIH}

Terimakasih yang sedalam-dalamnya kepada Direktur RS. Dr. M. Djamil Padang beserta staff dan kepala bagian rekam medis beserta staf yang telah memberikan izin untuk pengambilan data penelitian sehingga penelitian ini dapat diselesaikan

\section{DAFTAR PUSTAKA}

1. Robbins SL, Cortran. RS, Kumar V. Buku ajar patologi Robbins (terjemahan). Jakarta: EGC; 2007.

2. Dinas Kesehatan Padang. Profil kesehatan kota Padang tahun 2012.
3. Newby, LK, Hasselblad, V, Armstrong, PW. Timebased risk assesment after myocardial infarction: implications for timing of discharge and applications to medical decision-making. Eur Heart J. 2003; 24:182-9.

4. Ryan TJ, Antman. E, Brooks, NH. Update: ACC/AHA guidelines for the management of patients with acute myocardial infarction: executive summary and recommendations. A report of the American college of Cardiology/ American Heart Association task force on practice guidelines. Circulation. 1999:1016-30.

5. Irmalita. Terapi fibrinolitik pada infark miokard akut. Dalam: (Rilantono LI. Penyakit kardiovaskuler. Edisi ke-2. Jakarta: Badan Penerbit FKUI; 2011.

6. Kurniawan LB, Bahrun U. Hubungan kadar transaminase terhadap mortalitas dan lama perawatan pasien infark miokard. Jurnal Kedokteran YARSI. 2012. XX(1):29-35.

7. Fischbach FT, Dunning MB. A Manual of Laboratory and Diagnostic Tests. Edisi ke-8. Philadelphia: Lippincott Williams \& Wilkins; 2008.

8. Wagyu EA. Gambaran pasien infark miokard dengan elevasi ST (STEMI) yang dirawat di BLU RSUP Prof. dr. RD Kandou Manado Periode Januari 2010 sampai Desember 2010. Manado: Universitas Sam Ratulangi Manado; 2010.

9. Lazzeri C, Valente S, Tarquini R, Chiostri M, Picariello C, Gensini GF. Prognostic values of admission transaminases in ST-elevation myocardial infarction submitted to primary angioplasty. Med Sci Monit. 2010;16(12):567-4.

10. Brown CT. Penyakit aterosklerotik koroner, Dalam: Price SA, Wilson LM. Editor (penyunting). Patofisiologi konsep klinis proses-proses penyakit.. Edisi ke-6. .Elsevier Science. 2006. hlm. 576-93.

11. Viola V, Lori P, Nathan RE, Hal VB, Harlan MK. Sex based differences in early mortality after Myocardial Infarction. New England Journal Medicine. 1999. 217-25.

12. Steyn K, Sliwa K, Hawken S, Commerford P, Onen C, Damasceno. Risk factor associated with myocardial infarction in Africa: The Interheart Africa study. 2005. Circulation. 112:3554-61. 
13. Buja LM. Jantung . Dalam: Robbins, SL, Kumar V, editor (penyunting). Buku Ajar Patologi II. Edisi ke4. Jakarta: EGC;1995.

14. Peppes, V, Rammos, G, Manios, E, Koroboki, E, Rokas, S, Zakopoulos, N. Correlation between myocardial enzyme serum levels and markers of inflammation with severity of coronary artery disease and Gensini score: A hospital-based, prospective study in Greek patients. Clinical Interventions in Aging. 2008;3(4): 699-710.

15. Gray HH, Keith D, lain A, Morgan S, Morgan J. Lecture Notes: Kardiologi (terjemahan). . Edisi ke4. Jakarta: Erlangga. 2003.
16. Saputra TT. Hubungan lokasi infark dengan mortalitas pada pasien infark miokard akut yang dirawat. di ruang intensive cardiac care unit (ICCU) RSU Dokter Soedarso Pontianak. Pontianak: Fakultas Kedokteran Universitas Tanjungpura Pontianak. 2014

17. Pratiwi IF. Komplikasi pada pasien infark miokard akut ST-elevasi (STEMI) yang Mendapat Maupun Tidak Mendapat Terapi Reperfusi. Semarang: Fakultas Kedokteran Universitas Diponogoro. 2012

18. Alwi I. Infark miokard akut dengan elevasi ST Dalam: Sudoyo AW, Setiyohadi B, Alwi I. Buku Ajar Penyakit Dalam Jilid II. Edisi ke-5. Jakarta: Interna Publisihing. 2009. 